\title{
KEMAMPUAN MENULIS AWAL MELALUI PERMAINAN KREATIVITAS
}

\author{
Oleh: \\ Nur Halimah, S.Pd \\ SD Negeri 1 Pining, Gayo Lues \\ Email: halimahnur040@gmail.com
}

\begin{abstract}
Abstrak
Perkembangan menulis awal anak tidak akan berkembang begitu saja seiring dengan kematangan usia, tetapi adanya dorongan dari luar maka perkembangan tersebut dapat terjadi. Kegiatan bermain yang dilakukan bertujuan untuk mengembangkan menulis permulaan pada anak usia 5-6 tahun melalui kegiatan bermain kreatif pada anak SD tingkat rendah di SD Negeri 1 Pining, Kecamatan Pining Kabupaten Gayo Lues. Kemampuan menulis awalpada kelas rendah masih sangat kurang itu disebabkan keterbatasan guru dalam memberikan kegiatan yang kurang menarik bagi anak. Permainan kreatif sebagai salah satu alternatif yang bisa dilakukan guru agar dapat mengembangkan menulis awal dengan kegiatan yang menimbulkan rasa senang.
\end{abstract}

Kata Kunci : perkembangan menulis awal, bermain kreatif.

The children's early writing skill will not just develop in line with the growing of age, but the existence of force from outside makes the development occur. The creative playing activities aimed to develop the early writing skills of children aged 5-6 years old to the beginner level of elementary school in SD Negeri 1 Pining, Pining sub district, Gayo Lues regency. The early writing skill of the beginner level is so low and is caused by the teachers' lacking in giving less interesting activities. Creative game is one of alternatives for teachers to develop early writing skill while creating fun atmosphere.

Keywords: early writing development, creative playing

\section{PENDAHULUAN}

Terdapat 8 SD yang berada di kecamatan Pining, SD Negeri 1 Pining berada di pusat kecamatan yang berdekatan dengan SMP dan kantor kecamatan. Jarak tempuh dari Kabupaten menuju Kecamatan Pining adalah $44 \mathrm{~km}$ menggunakan transportasi darat.Medan yang curam naik turun membuat Kecamatan ini semakin tertinggal. Terdapat sembilan guru yang tercatat sebagai guru tetap di sekolah tersebut, dan satu pegawai TU.Siswa di SD 1 Pining mulai dari kelas satu sampai kelas enam berjumlah sekitar 168 siswa dengan rincian 20 siswa kelas I, 17 siswa kelas II, 25 siswa kelas III, 33 kelas IV, 39 kelas V dan sebanyak 34 siswa kelas VI.

Umumnya masyarakat di Gayo memasukan anak mereka ke sekolah SD pada saat usia 5-6 tahun, dengan berbagai alasan salah satunya karena hanya mengikuti teman yang lebih dahulu sekolah di SD. Masih jarangnya informasi mengenai perkembangan anak yang seharusnya dimulai saat usia dini membuat orang tua lebih percaya pada sekolah dasar sebagai awal anak mereka memperoleh pendidikan. Latar belakang orangtua yang minim akan pendidikan membuat anak- 
anaknya juga tidak memperolehkan perkembangan dan wadah yang tepat.Terbukti bahwa terdapat beberapa siswa kelas II yang harusnya naik kekelas III, tetapi tidak naik karena mereka untuk menggambar sederhana saja masih kesulitan, apalagi untuk menulis angka dan huruf sama sekali belum beraturan.

Menurut John Deway dalam bukunya Democracy And Aducation (dalam Dwi Siswoyo: 18) Pendidikan adalah rekonstruksi atau pengalaman yang menambah makna pengalaman dan menambah kemampuan untuk mengarahkan pengalaman selanjutnya. Pendidikan yang dikembangkan untuk Anak Usia Dini dikemas dalam suatu kegiatan permain yang menarik bagi anak.

Permainan yang dikembangkan oleh guru belum sepenuhnya mengkait pada aspek perkembangan anak. Permainan di Sekolah yang biasa dipakai hanya permainan untuk fisik motorik kasar seperti bermain bola dilapangan, tenis dan badminton. Tetapi untuk permainan yang khusus mengembangkanperkembangan bahasa baru sedikit, cenderung tidak gunakan. Kegiatan disekolah yang terpatok dengan papan tulis, buku dan pensil yang setiap harinya selalu diberikan anak, membuat anak cepat bosan sehingga perkembangan anak tidak maksimal karena hal tersebut.

Keterbatasan guru dalam mengajar, misalnya datang hanya sebulan sekali membuat anak semakin tidak terstimulus dengan baik, kalau dilihat anak SD ditempat ini sering masuk sekolah tetapi jarang guru yang datang.

Agar perkembangan menulis awal dapat terlaksana dengan baik, maka guru dituntut untuk mengembangkan permainan kreatif, seperti permainan membentuk huruf dari plastisin, menuliskan huruf pada media pasir, mewarnai huruf, membuat garis lurus. Dengan harapan bisa meningkatkan perkembangan menulis awal pada siswa kelas I SD Negeri Pining.

\section{PEMBAHASAN}

Dalam rangka mengembangkan bahasa "kemampuan menulis awal pada aank" Guru mulai mengembangkan model pembelajaran berbeda dengan yang sudah ada sebelumnya. Dimulai menyusun perangkat, penyiapan media, dan persiapan untuk media permainan kreativitas tersebut. Permainan tersebut antara lain :

1. Membuat bentuk huruf dari plastisin ( tepung )

Plastisin yang terbuat dari tepung terigu, campurkan garam dengan di beri pewarna makanan, minyak sedikit dan diuleni dengan air hangat, dapat menjadikan permainan membentuk akan terasa menyenangkan.

2. Bermain menuliskan huruf pada media pasir

Bermain menggunakan pasir, guru mengajak anak untuk berkeliling di lingkungan sekolah dan melakukan kegiatan out door.

3. Menebalkan huruf

Pada permainan ketiga adalah menebalkan huruf. Guru menyediakan 4-5 huruf dalam satu lembar kerja dan digandakan sesuai jumlah murid.

Dengan tema kebutuhanku di buat gambar yang belakangnya terdapat garis putus-putus. Seperti baju, buku, tas, makan, mandi.

4. Mewarnai kata

Guru menyiapkan kertas ukuran kecil yang berisi tulisan dan gambar anak diminta mewarnai gambar dan kata tersebut.

5. Membuat garis lurus

Guru menyediakan lembar kertas kosong pada anak, anak diminta untuk menuliskan garis lurus. Kegiatan ini bertujuan untuk mengetahui kesiapan anak untuk memperoleh perkembangan lanjutan. 


\section{Perkembangan Anak}

Perkembangan anak seharusnya mendapat perhatian yang serius karena didalamnya saling berkaitan antara pengembangan satu dan yang lain. Perkembangan Individu menyangkut berbagai macam dimensi, atau ranah perkembangan seperti faktor fisik, intelektual menyangkut perkembangan seperti faktor fisik, intelektual meyangkut perkembangan kognitif, bahasa emosional, sosial dan moral (Rita Eka Izzaty, 2008:4)

Anak dengan rentag usia 5-6 tahun tergolong pada tahapan periode operasi awal, perkembangan pada tahap ini telah terjadi perkembangan imajinasi dan kecakapan mengingat, maka belajar merupakan yang bersifat akumulatif dan tidak bergantung kepada kehadiran objek dan pengalaman kongkret (Hasto Daryanto, 2010: 47). Anak mulai terangsang untuk membayangkan hasilhasil pengamatan dari kegiatan yang telah dilakukan.

Dalam perkembangan bahasa terdapat tahapan-tahapan yang harus dilalui anak, sehingga anak dapat mencapai tahap perkembangannya, dalam perkembangan bahasa kemampuan menulis dianggap perlu untuk berkomunikasi selain dengan lisan tetapi juga menggunakan komunikasi tulis. Cara belajar menulis permulaan dilakukan setahap demi setahap dengan latihan terus menurus seiring dengan perkembangan membaca awal (Rita Eka Izzaty, 2008:108)

Bermain menjadi salah satu kegiatan yang menimbulkan rasa senang, tidak perlu ada paksaan dari pihak luar untuk melakukan kegiatan bermain tersebut, sehingga diharapkan melalui kegiatan bermain anak mampu berkembangan dengan maksimal.

Berdasarkan beberapa pendapat terseubut dapat dijelaskan bahwa kemampuan menulis permulaan dapat di kembangkan secara maksimal dengan permainan-permainan kreatif yang dikembangkan oleh guru.

\section{Implementasi}

Bermain plastisin, plastisin warna dibuat menggunakan bahan alami sehingga tidak membahayakan bagi anak. awal masuk kedalam kelas guru melakukan pendalaman materi. Media gambar dikenalkan dalam proses pendalaman tersebut, setelah perkenalan materi, setelah kegiatan tersebut guru mulai mengenalkan apa media atau bahan untuk permainan yang akan dilakukan. Setelah guru mencoba mendemonstrasikan cara bermain yaitu membuat tiruan huruf $a, b$ dan $c$, anak mencoba sendiri membuat sendiri dengan kreasi yang berbeda-beda.

Bermain menggunakan Pasir

Pada kegiatan bermain pasir, anak dan guru berkeliling diarea sekolah, dalam rangka mengenalkan lingkungan sekitar. Guru mulai melakukan pendalaman materi bahan ajar mengenai pasir. Selanjutnya guru membuat suatu angka satu pada pasir tersebut. Anak segera menirukan permainan tersebut.

Bermainan mewarnai kata

Guru menyiapkan alat dan media untuk melakukan permainan tersebut, pada saat kegiatan pembelajaran berlangsung guru membawa kartu gambar ukuran A4 yang di bawah gambar terdapat tulisan kata. Anak diminta untuk mewarnai gambar tersebut dan tulisan tersebut dengan media krayon.

Membuat garis lurus

Guru menyiapkan alat dan medianya yaitu berupak kertas kosong yang terdapat garisgaris halus, Pada kegiatan permainan ini, anak menarik garis yang sudah ada, kegiatan tersebut dilakukan 5-6 kali.

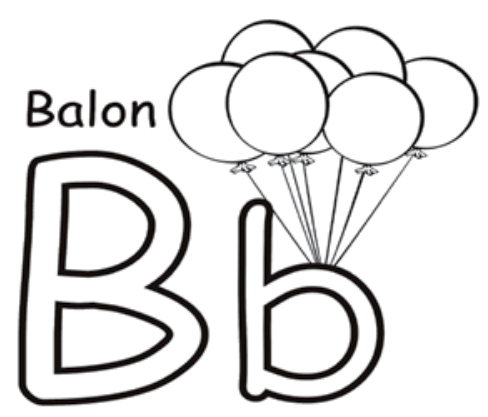


Gambar 1.

Kegiatan untuk menulis awal pada anak

\section{KESIMPULAN}

Pengembanganyang tidak terstimulus dengan baik akan menimbulkan keterlambatan dalam proses belajarnya. Anak Usia 5-6 tahun, pada dasarnya memerlukan stimulus yang tepat untuk mencapai tingkat perkembangannya. Tetapi pada kenyataannya masih banyak anak yang belum mencapai perkembangan dengan maksimal. Di kelas rendah SD Negeri 1 Pining terdapat beberapa siswa yang sama sekali belum bisa untuk menulis.

Kegiatan yang dikembangkan guru melalui permainan kreatif seperti membuat huruf dari playdough, bermain pada media pasir, mewarnai kata, membuat garis lurus. Pada kegiatan permainan tersebut diperoleh bahwa kemampuan menulis awal anak dapat dikembangkan melalui permainan yang menimbulkan rasa ketertarikan anak seperti permainan kreatif diatas.

\section{DAFTAR PUSTAKA}

Rita Eka Izzaty, dkk. 2008 Perkembangan Peserta Didik. Yogyakarta: UNY Press

Hasto Daryanto. 2010 Profesi Pendidikan Anak Usia Dini. Surakarta.

Dwi Siswoyo, dkk. 2007 Ilmu Pendidikan. Yogyakata: UNY 